\title{
A Conceptual Model of Engineers' Retention: A Review of Talent Management Practices in Manufacturing Sector
}

Nurul Ezaili Alias, Norashikin Hussein, Wei-Loon, Koe, Rozana Othman, Najihah Hanisah Marmaya

To Link this Article: http://dx.doi.org/10.6007/IJARBSS/v12-i1/12136

DOI:10.6007/IJARBSS/v12-i1/12136

Received: 06 November 2021, Revised: 12 December 2021, Accepted: 01 January 2022

Published Online: 23 January 2022

In-Text Citation: (Alias et al., 2022)

To Cite this Article: Alias, N. E., Hussein, N., Wei-Loon, K., Othman, R., \& Marmaya, N. H. (2022). A Conceptual Model of Engineers' Retention: A Review of Talent Management Practices in Manufacturing Sector. International Journal of Academic Research in Business and Social Sciences, 12(1), 2277- 2295.

Copyright: (c) 2022 The Author(s)

Published by Human Resource Management Academic Research Society (www.hrmars.com)

This article is published under the Creative Commons Attribution (CC BY 4.0) license. Anyone may reproduce, distribute, translate and create derivative works of this article (for both commercial and non0-commercial purposes), subject to full attribution to the original publication and authors. The full terms of this license may be seen at: http://creativecommons.org/licences/by/4.0/legalcode

Vol. 12, No. 1, 2022, Pg. 2277- 2295

Full Terms \& Conditions of access and use can be found at http://hrmars.com/index.php/pages/detail/publication-ethics 


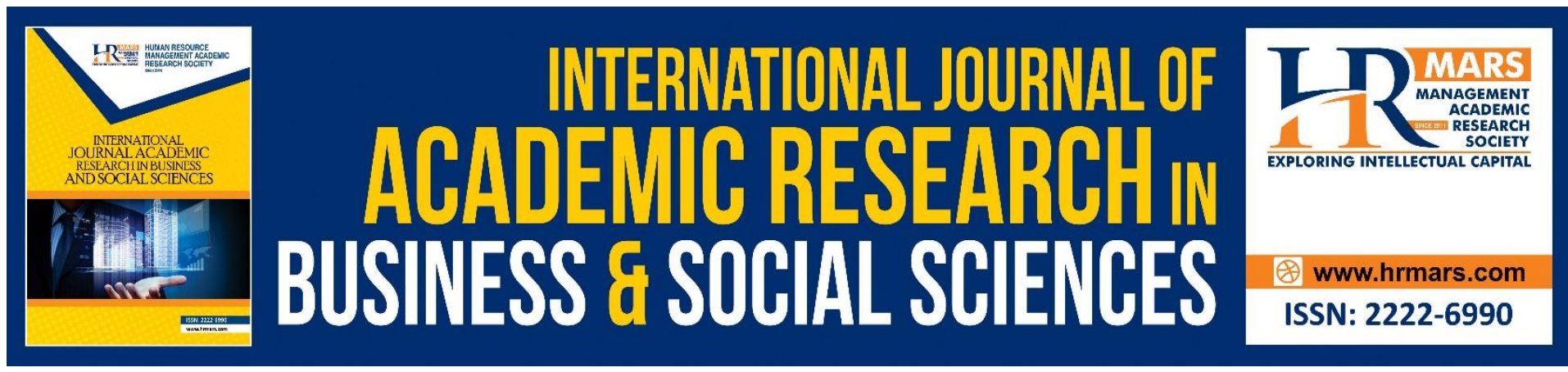

\title{
A Conceptual Model of Engineers' Retention: A Review of Talent Management Practices in Manufacturing Sector
}

\author{
Nurul Ezaili Alias \\ Faculty of Business and Management, Universiti Teknologi MARA, Melaka, 110 Off Jalan \\ Hang Tuah, 75350, Melaka, Malaysia \\ Email: nurulezaili.alias@gmail.com \\ Norashikin Hussein \\ Faculty of Business and Management, Universiti Teknologi MARA, Selangor, Malaysia \\ Email: shikin6320@uitm.edu.my
}

\section{Wei-Loon, Koe, Rozana Othman, Najihah Hanisah Marmaya}

Faculty of Business and Management, Universiti Teknologi MARA, Melaka, Malaysia

\begin{abstract}
This paper presents the conceptual model of TM practices on engineers' ITS in Malaysia's manufacturing sector. This article argues that the best retention strategy for employees fails to capture the peculiarities of HRM practices amongst engineers. The article instead articulates the view that the different and unique KSAs of engineers allow manufacturing companies to adopt distinct practices, which may not cohere with the perspective of standard HRM practices within organisations. The article aims to further the thesis that the approach to TM practices does not always match with manufacturing engineers because of their unique characteristics as talent resources. This makes TM prescriptions for workforces invalid on engineers, especially in the manufacturing sector. As this is a theoretical-based article, a systematic literature review method was conducted to draw findings and conclusions. The findings of the article show that the engineers' high shortages and low retention in the market make it hard to generalise TM practises across all levels of an organisation. This shows that the practices that work in companies may not always work at the same level of an organisation. TM practices in manufacturing companies must be reviewed and modified in order to retain engineers for a long time and sustain the company's competitive advantage. The findings also give future research a better idea of how manufacturing companies manage their talent resources by revealing the company's unique way of managing talent, especially engineering talent. The article is important because it has opened up new avenues to look at TM and how it works for manufacturing engineers.
\end{abstract}

Keywords: Talent Management, Employer Branding, Retention, Engineers, Manufacturing, Resource-Based View Theory, Social Exchange Theory 


\section{Introduction}

The high global shortage and uncertain retention behaviours amongst engineers have become one of the most concerning to organizational Human Resource Management (HRM). Although intention to stay (ITS) academic research has shown intense growth in recent literature, organisations still suffer from low retention among engineers. Engineer shortages have shaped their behaviour to actively search and hop to other organisations for more attractive employment opportunities (Poisat et al., 2018; Sparrow, 2019). The is no concrete antecedents to influence an engineer's ITS and yet to be ascertained (Bigliardi et al., 2005; Lee et al., 2018).

Meanwhile, previous research suggests that Talent Management (TM) is a crucial strategy to influence individual talents' ITS (i.e., engineers) (Gupta, 2019b; Mohammed et al., 2020). Previous studies have explored the implementation of TM practices in various countries due to continuous talent shortages. However, Anlesinya, Dartey-Baah, \& Amponsah-Tawiah (2019) argued the statement of scholars based in Europe are leading in TM discourse. Based on their systematic literature review, the Asian context has also emerged as the leading region in empirical research. The popular notion of the TM literature from US-centric is also a bit exaggerated. They concluded that not only among European, TM research has also been led by Asian scholars and contexts (Anlesinya, Amponsah-Tawiah, et al., 2019), but research specifically in Malaysia is severely underrepresented (Abdul Hamid, 2016; Abdull Rahman, 2012).

Therefore, the rationale for conceptualising this article is to close the research and theoretical gaps in the existing literature by introducing an exclusive approach of TM practices (i.e., performance management, career development, and employer branding) in predicting engineers' ITS.

\section{Problem Statement}

This article argues that most TM literature investigated a practical set of TM practices that contribute to talent retention (for example, management positions Shikweni et al (2019); knowledge workers Sutherland \& Jordaan (2004); academicians Zeeshan (2020a); PhD holders who contribute to the innovative achievements (Sinniah et al., 2019); ICT engineers Ahmed \& Yang (2017); Singh et al (2013); IT specialists Eom et al (2019); professional auditors (Valeau et al., 2019). However, very little scholarly research on TM practices and retention among engineers has been implemented (Nittala \& Jesiek, 2018; Van Hoek \& Schultz, 2013).

Furthermore, very little research on TM practices and retention has been found in the manufacturing sector (Osman et al., 2017, 2018; Subramaniam et al., 2019). Most of the previous findings were found from sector of construction (Shikweni et al., 2019); education (Zeeshan, 2020); ICT (Ahmed \& Yang, 2017); GLCs (Government-linked Companies) (Isa et al., 2018); private organisations (Singh \& Sharma, 2015); hospital (Eltaybani et al., 2018). This reasoning is derived from the previous studies (Whysall et al., 2019) who claim that most TM literature were focused on inclusive approach and therefore what is ideal to retain engineers for a long time in an uncertain employment market is to implement an exclusive approach to TM practices for engineers in the manufacturing sector.

Therefore, the article seeks to explore the veracity of the resources-based view (RBV) and social exchange theory (SET) view that a prescribed set of TM practices can be applied to engineers' retention generically to all organisations, global or local, with the same result or may be, as Alias, Roni, Merga, \& Ismail (2017) note, there is a distinctive difference in 
approach to TM practices on specific talent (i.e., engineers) to continue to sustain the organisational competitive advantage and retain them for a long time.

\section{Theoretical Underpinnings}

According to Maurya \& Agarwal (2018), there are glaring differences of opinion on what constitutes TM in the talent workforce within organisations. Based on the theoretical foundation gaps, the RBV theory (Barney, 1991) and SET (Blau, 1964) still lack empirical findings to address TM practices in predicting engineers' ITS. The conceptual model of the article is based on the RBV theory, with the SET as the primary component of the theoretical framework. These underpinning theories are specifically selected to address the issue of talent shortages and retention (among manufacturing engineers) in Malaysia. This is achieved by conceptualising the tangible and intangible resources of the RBV (i.e., TM practices), and relationships between variables are explained under SET.

The combination resources in RBV theory (TM practices as tangible and intangible resources) also allows the current study to investigate the connection between TM practice resources in achieving high talent retention and sustainable competitive advantage (Narayanan et al., 2019). The lack of studies examining TM resources underpinned by the foundation theory of RBV theory and SET also provides the research gaps and justifies the study theoretically (Mensah, 2019). This article therefore seeks to lay bare literature and fulfil the theoretical foundation gaps with the following aims: a) to enhance individual talent's attitudes and behaviours toward TM practices, $b$ ) to resolve the continuous issues of managing engineer shortages and low retention, and c) to extend years of service among engineers.

\section{The Scenario of Engineers' Retention}

Today, employers' primary concern is to retain their top talents, especially in identifying the engineers' underlying behaviours and attitudes. Talent retention is becoming a significant determinant of an organisation's long-term survival, competitiveness, and dominance (Tanwar \& Prasad, 2016). Hence, ITS has become a significant variable in the HRM and organisational research fields to measure the retention level among talents in organisations (Alves et al., 2020). ITS has been extensively explained as an individual employee's consciousness and intentional determination to remain with their current employment on a long-term basis (Bangwal \& Tiwari, 2019). ITS has also been used to accommodate shortages among talents with specific knowledge, skills, and abilities (KSAs).

Engineering institutions worldwide have recognised the significance of engineering talents in achieving Sustainable Development Goals (SDGs). Most world countries engineering institutions have collaborated with their members, educational institutions, government, and industry to address the need for engineering capacity and engineers' quality. Further, the World Federation of Engineering Organisations (WFEO) and the ASEAN Federation of Engineering Organisations (AFEO) declared the continuation to accelerate the SDGs' implementation and lead the engineering profession to the main SDGs to build a fairer, safer, and more sustainable world, especially as aimed in Goal 3, Good Health and Well-Being (ASEAN Federation of Engineering Organisations, 2021; WFEO, 2020b, 2020a). Furthermore, the local Institution of Engineers Malaysia (IEM) also continued its efforts to deliver initiatives and events to create awareness and promote sustainability in managing, innovating, and developing engineering projects in any circumstance (IEM, 2020).

However, the issue of the global engineer shortage has been one of the most concerning issues today. The phenomenon of talent competition, or "war for talent" due to talent 
shortages, has become a priority issue, specifically among engineers (Bass et al., 2018). The Asian engineers' shortage is also not a new issue and has become a significant concern among employers, especially in manufacturing engineering. Attracting and retaining engineers are critical human capital challenges that have become a significant concern for many Asian organisations (Yee et al., 2012). Furthermore, in the local position, Malaysia is also facing a shortage of engineers.

According to the Malaysian Education Ministry, only a few graduated engineers registered their engineering qualifications legally with the Board of Engineers Malaysia (BEM) (Harun, 2020). Under the Act, individuals who are not registered with the BEM as professional engineers are not permitted to practice, conduct business, or work as engineers, collect any fee, or charge remuneration for professional services provided as engineers. In addition to the issue, the Eleventh Malaysia Plan 2016-2020 has anticipated that the nation will experience a significant shortage of skilled and professional workers (including engineers) (ILMIA, 2018; Mitchell et al., 2004). Malaysia is still facing a shortage of engineers and retention issues in the employment market, especially in manufacturing companies (StudyMalaysia.com, 2020). Although organisations have implemented various strategies to retain their engineers, they still face difficulties keeping them longer (Chamchan \& Kittisuksathit, 2019).

\section{Research Design}

This article is attempting to explore the validity of the perception that TM practices are generic and therefore can be applied with success in any organisation, regardless of shape, size, or type of employees. In the interest of striking a balance between the recent literature trends and the need for an in-depth analysis, a systematic search of the literature was conducted, and the identified studies were matched against several criteria. Firstly, in peerreviewed journals, the literature search was conducted on the following academic databases: Scopus and Web of Science (WoS), using an advanced and rigorous literature search: ("talent management") AND (retention OR stay OR remain) AND engineer. As recommended by Bergh (2012) this article used Boolean logic to refine the literature searches to the range of 100-150 hits per keyword search. This had the effect of focusing the literature searches on the core thesis proposed in this article. In addition, selective searches were carried out on Google Scholar using the same search terminology to widen the literature reach. Then, all relevant articles from various peer-reviewed journals were tabled into Microsoft Excel database established by the researchers. Accumulatively, 150 journal articles within the year of 20052021 (excluding the obtained dissertation and theses) have been thoroughly reviewed and keyed-in into Excel database in order to examine the precise research gaps in the field of study.

\section{Data Analysis}

Given the qualitative approach adopted to produce this article, a thematic analysis was applied to produce meanings and draw conclusions in this article. According to Braun and Clarke (2006), thematic analysis involves the repeated reading and analysing of texts and the identification of key themes and concepts drawn from across diverse literature claims. Likewise, this article used thematic analysis to isolate literature that reveals that TM practices (i.e., performance management, career development, and employer branding) amongst engineers in the manufacturing sector are unique and appropriate for their human capital and retention strategies constraints. 


\section{Observations and Reflections}

As previously reported, the practice of TM on engineering talent is unique as compared to what prevails in other human resource practices. Collings \& Mellahi (2009) and Festing \& Schäfer (2014) concur and report that talent is perceived as rare, valuable, and difficult to imitate, and is therefore classified as human capital with high value. When compared to other human resources in an organization, talent resources are viewed as strategic resources. Talent has a natural ability to create a competitive advantage for organisations and impact organisational performance (Lepak \& Snell, 1999; Tlaiss et al., 2017). In the literature, talent is typically found and characterised as specific KSAs and attributes in their specific context (Festing \& Schäfer, 2014).

In fact, as Ingersoll (2002); Rahman (2012) explain, there are various employees with specific KSAs in organisations who are considered talented in their respective fields. Traditionally, doctors, lawyers, architects, dentists, and accountants belong to the western culture of talents in private industries. Evolutionary engineers came to the employment market, especially in the emerging industrialising economies, and have been categorised as highly skilled and technical workers in an organisation. Due to their minimum requirement to be an engineer, which at least to attain a certain level of academic qualification, professional certificates, or working experience, engineers are classified as technical elites employed in industrial organisations.

Meanwhile, in a local study, Abdul Hamid \& Yahya (2016) asserted the minimum academic qualifications an engineer should possess. An engineer must have a bachelor's degree in any engineering-related field and experience in the job position as an engineer through formal education - for instance, an internship programme or practical training with any one or more organisations. With the proper education, they learned specific engineering and related field KSAs to meet the job demands in the employment market. Those KSAs would also help them implement the job effectively and efficiently, increasing their motivation and satisfaction.

Additionally, engineers have been widely considered and accepted by many organisations as their critical workforce and hard-to-replace resources. Hence, effective management and development of engineers has become a significant agenda item where top management believes these talent resources can enhance an organisation's strength and competitive position (Nittala \& Jesiek, 2018). It can be said that engineers are a talent resource in organisations and have acquired specific and in-depth KSAs that make them hard to replace in an organisation, and this visualises the nature of engineers' employment (Gandy et al., 2018). Although previous studies have empirically found the determinants of engineers' retention, the low retention rate among this talent continues to jeopardise organisational stability and performance. This article surmises that it does not follow that there is anything wrong with TM practices in organisations, but rather shows that TM practices on specific engineering talents are unique and suited to the significant economic growth and environmental circumstances of the manufacturing sector.

\section{Significant Contributions of Engineers in the Manufacturing Sector in Malaysia}

In Malaysia, there are various sectors for engineers to serve, including manufacturing, consultation, research and development, construction, building services, maintenance, plantation, aviation, maritime, sales, and oil and gas industries, as well as institutions of higher learning as an engineering academician (Harun, 2020). In conjunction with that, a wellestablished recruitment agency in Malaysia (i.e., JobStreet Malaysia) reports that the top 
three career opportunities that are still relevant are in manufacturing, information and technology (IT) and banking (StudyMalaysia.com, 2020).

Among various sectors, manufacturing is a dominant sector and a strong indicator of economic growth. Fazil (2020) stated that engineers in the manufacturing sector put Malaysia in good stead as the nation heads towards Industrial Revolution 4.0 (IR 4.0). With artificial intelligence (AI) advancements, new engineering-related jobs have emerged in this sector, such as automation engineers, robotics engineers, and Al engineers. The manufacturing sector has been recognised as crucial for the nation's development and sustainability and has recorded impressive growth recently (Malaysia Labour Market Review by DOSM, 2020b). Hence, it is undeniably claimed that the manufacturing sector is important for both developed and emerging economies (DOSM, 2020; MIDA Insights, 2020), and the engineering KSAs are essential determinants contributing to economic growth and shrinkage (Deloitte, 2020; MIDA, 2019).

\section{Intention to Stay among Manufacturing Engineers}

Due to a high demand for engineering jobs and a shortage of engineers in the manufacturing sector, organisations struggled to attract and retain their existing engineers. However, this talent has been recognised as having some lingering behavioural issues (McDonnell et al., 2017; Zheng, 2009). Yet, the low level of ITS in an organisation may cause the industry to lose its competitive advantage in retaining the engineers' workforce, especially in manufacturing (Bethke-Langenegger et al., 2011).

The manufacturing sector is always associated with engineers, who are characterised as 'knowledge workers.' The concept of 'knowledge worker' has developed alongside manufacturing engineers' retention literature. A 'knowledge worker' mainly creates, distributes, and applies knowledge on the job, while a 'worker' usually uses knowledge to perform the job (Rahman, 2012). As knowledge workers, engineers can apply theoretical and analytical knowledge and work smarter and faster than other employees (Lejdeby \& Östman, 2019). In a similar study, Khalid \& Nawab (2018) found that engineers are usually looking forward to develop and advance opportunities in their career with their current employer. Further, manufacturing engineers have the behaviour to leave organisations if they received lack of career development opportunities. They will seek new employment in the manufacturing employment market that is more promising and offers a variety of choices.

In the Malaysian manufacturing context, such a work environment and nature reinforce human behaviour (Pervin, 1989). The specific aspects of the manufacturing working environment in Malaysia are likely to affect engineers' retention. It follows, then, that training and development and various aspects of the work environment must be given serious attention to address engineer retention issues in the manufacturing sector (Subramaniam et al., 2019). Engineers in developed countries consider manufacturing engineering work and infrastructure always needs expansion and development. Therefore, it is essential to review and revise the engineers' retention strategies (Lejdeby \& Östman, 2019). Yet, many employment factors that can affect higher retention have not been adequately fulfilled, particularly in sector where competition for highly skilled employees is fierce, such as in the manufacturing industry (Subramaniam et al., 2019).

As talent shortages continue to be a critical issue and phenomenon, the labour market has devolved into a "war for talent" (Palmer, 2003). Hence, organisations have started to concern about losing their talents because the unique KSAs may also be more attractive to their competitors, especially among those talents that are in short supply in the market (Rezaei \& 
Beyerlein, 2018; Zheng, 2009). As a result, organisations begin to evaluate and revise their strategic HR planning for long-term profitability and performance. Since then, organisations have continued to develop competitive strategies to attract and retain top talent (Alias, Othman, et al., 2017; Alves et al., 2020).

\section{The Concept of Talent Management Practices}

The famous idiom in the TM field is the "war for talent." Since the 2000s, many employers have failed to retain their talents from departing to other competitors (Ngan \& Tze-Ngai Vong, 2019). Consequently, a constant review and identification of retention factors among engineers continue to capture the attention of academics and practitioners. Successfully determined engineers' retention factors can enhance employers' understanding of their potential talent's employment needs (Smyth \& Zimba, 2019). Thus, TM practice is one of the retention strategies that continually identifies the factors of engineers' decision to stay (Yelamanchili, 2018).

\section{Exclusive Approach to Talent Management}

Conceptually, there are two (2) approaches in implementing TM practices: exclusive and inclusive. The exclusive approach focuses on specific talent segmentation and treats them as an elite subset of its population. On the contrary, the inclusive approach believes that everyone in the organisation is treated as talent potential. Previous scholars, however, continue to argue about whether the TM approach should be implemented inclusively or exclusively (Pant \& Venkateswaran, 2019). Above all the contradictory perspectives on the TM approach, in relevance to previous studies, they recommend pursuing an exclusive approach to TM practice. The approach is matched to solve the specific talent shortages in the employment market, where their retention behaviour is nauseous (Shikweni et al., 2019). Managers of Asian Multinational Corporations (MNCs) claim to follow an inclusive TM strategy, but when it comes to talent, an elitist mindset emerges. Talents are employees with the highest education, highest potential, and unique KSAs (Cooke et al., 2014). Hence, lles et al (2010) and Li et al. (2018) also support the exclusive approach as the preferred strategy among Asian organisations. The exclusive approach of TM practice is far more common and relevant in the practice of Asian organisations as emerging economies than the other approach in developed countries (Vnouckova et al., 2018). Hence, this justifies why organisations consider some talent or positions as rare, valuable, and difficult to imitate (Festing \& Schäfer, 2014) and operationalised them as human capital that offers high value to the organisation (Lepak \& Snell, 1999). Not only that, top management identified some employee talents as strategic resources for the organisations as they can create a sustainable competitive advantage that impacts performance and profitability (Tlaiss et al., 2017).

In addition, TM practices have received growing devotion over the past decade to curbing talent shortages and retention issues, but the field study still lacks intellectual and theoretical foundations. Further, previous research on TM practices and employee retention among specific talents or KSAs is still scarce in providing empirical evidence (Neri \& Wilkins, 2019). Not to mention, only a few studies have explored the exclusive approach of TM practices on individual engineers' ITS (Vnouckova et al., 2018). Previous studies have recommended an exclusive approach to TM practices on engineers' ITS (Nittala \& Jesiek, 2018). Therefore, this article conceptualised the exclusive approach to TM practices on engineers in the manufacturing sector. 


\section{Talent Management Practices and Intention to Stay of Engineers}

From an extensive and rigorous literature review that has been conducted, the researchers have identified the three significant practices of managing engineering talents in previous studies that significantly influenced engineers' retention. Similarly, the SET also supports this notion and RBV theory, which describes TM practices (i.e., performance management, career development, and employer branding) as valuable resources for organisational sustained competitive advantage (Barney, 1991, 2001; Blau, 1964; Blau, 2017).

\section{TM Practice (Performance Management)}

Performance management is defined as the extent to which organisations enhance a sense of performance standards' meaningfulness through goal setting, inform and guide talented employees to experience the challenge and, hence, motivate them to perform better at their work (Tymon et al., 2010a). Continuous feedback is given to help the talented employees grow more and feel motivated to perform better in the future (Shyam Nivedhan \& Priyadarshini, 2018). Especially among professional and talented employees, feedback always inspires them to give their best (Doh et al., 2011). For example, engineers prefer to discuss their goal-setting or performance standards that include clarifying role expectations and bringing out the abilities (Mwanzi et al., 2017). Performance management also serves as a strategic tool in making administrative decisions, mainly those concerning promotions and merit pay increases, indicating that they are a valued part of the organisation. Consequently, talented employees perceive these decisions as being made through a fair and equitable process (Shikweni et al., 2019).

A study by Alias, Roni, Merga, Ismail, et al. (2017) confirmed the relationship between performance management and employee retention. It was found that performance management is a significant predictor in TM practice, and the usage of performance review and feedback is most valuable to talented employees in Malaysian ICT companies. Similarly, performance management was also found to influence intention to stay among talented employees (Baharin \& Hanafi, 2018). From the engineers' context, studies (e.g., Sutherland \& Jordaan, 2004; Yee et al., 2012) found that performance management was related to positive engineers' retention.

\section{TM Practice (Career Development)}

Career development is defined as an organisational strategy to maintain and enhance talented employees' career paths through their set of KSAs and align them with the organisation's strategic goals (Paré \& Tremblay, 2007). Career development is an advancement opportunity to improve talented employees and signal that top management is willing to invest in them beyond short-term returns, i.e., performance and productivity (Younas \& Bari, 2020). Due to the rapid advancement of technology, engineers must keep up with the changes and acquire new KSAs for future career development as well as for engineering product needs and demands (Letchmiah \& Thomas, 2017). As mentioned above, engineers seek a working environment that offers the opportunity to be promoted in the future. Hence, a lack of career development and promotional opportunities increase the possibility of talent loss (Stahl et al., 2012).

Findings of studies (e.g., Singh \& Sharma, 2015; Tlaiss et al., 2017) relating to career development on TM practices and employee retention have been consistent in the literature. From Asian context, previous studies (e.g., Alias, Othman, et al., 2017; Baharin \& Hanafi, 2018) found that career development was related to positive employees' ITS. From the engineers' 
context, studies (e.g., Anvari et al., 2014; Rahim et al., 2019) found that career development practices were related to positive engineers' retention.

\section{TM Practice (Employer Branding)}

Ambler \& Barrow (1996) defined employer branding as a cluster of organisational benefits in terms of functional, economic, and psychological that the employing organisation provides. As Ambler \& Barrow (1996) state, employer branding is an intangible asset that must be cultivated if performance is to be optimised. There are two perspectives of employer branding, internal and external. Lloyd identified employer branding as the organisations total effort to communicate with existing talents (internal branding) or potential candidates (external branding) why this company is a 'desirable place to work'(Lloyd, 2002). Backhaus \& Tikoo (2004) state that internal employer branding focuses on retaining employees who are difficult to replicate in other organisations. Internal employer branding is successful for a company if its employees thrive at work, become loyal, and act as great ambassadors for the organisation. Meanwhile, external employer branding aims to attract potential candidates by engaging in organisational activities that promote social responsibility and trustworthiness. However, the concept of internal employer branding has increased the attention of academics following a growing interest in the management and retention of talents.

Most previous scholars in TM studies have empirically researched the influence of the internal perspective of employer branding on retention among talents or specific KSAs in organisations (Alves et al., 2020; Espinoza et al., 2019; Maheshwari et al., 2017; Shikweni et al., 2019; Tymon et al., 2010b). Maurya \& Agarwal (2018) state that the internal perspective of employer branding is complemented by the current issue of talent shortages and low retention rates among talent in organisations. Further, Maurya \& Agarwal (2018) and Tanwar \& Prasad (2016) recommended future research to further study employer branding on existing talents in organisations to continuously ascertain their desired retention behaviour. According to Ramaiah \& Raut (2014), the value of employer branding that an employer has established among its internal consumers (i.e., existing talents) can retain them for a long period. TM practice such as employer branding is also a significant predictor of high ITS level among engineers (Gandy et al., 2018; Nittala \& Jesiek, 2018; Pant \& Venkateswaran, 2019; Ramli, 2016; Van Hoek \& Schultz, 2013).

\section{Proposed Conceptual Model}

lack of studies examining TM resources underpinned by the foundation theory of RBV theory and SET also provides the research gaps and justifies the study theoretically

As mentioned above, the lack of studies examining TM resources underpinned by the foundation theory of RBV theory and SET also provides the research gaps and justifies the study theoretically. The two crucial resources theorised by RBV theory are tangible and intangible resources in TM practices to sustain the retention level among employee talents with specific KSAs in organisations (i.e., engineers). The tangible resources consist of (TM practice: performance management) and intangible resources consist of (TM practice: career development and employer branding) will be examined to have a significant relationship with engineers' ITS. Figure 1 presents the relationships between TM practices (i.e., performance management, career development, and employer branding) and ITS. 


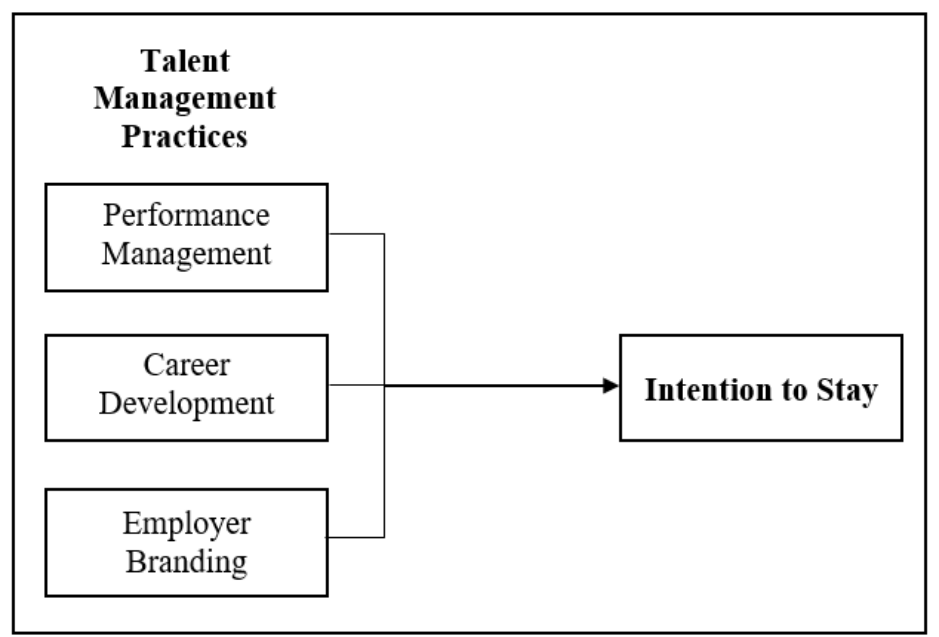

Figure 1 Conceptual Model for Talent Management Practices on Engineers' Intention to Stay

\section{Evaluation of Contribution}

This theoretical article is an attempt to draw the line between TM practices-retention on engineering talents and those prevailing in other organisations on all employees. The article does this by exploring the veracity of the resources-based view (RBV) and social exchange theory (SET) view that a prescribed set of TM practices can be applied to engineers' retention generically to all organisations global or local with the same result or may be. In other words, there is a distinctive difference in approach to TM practices on specific talent (i.e., engineers) to continue sustain the organisational competitive advantage and retaining them for a long time. The article is therefore making a significant contribution to the field of TM on engineers by revealing the exclusive approach to management of organisational talent resources.

There are several expected contributions where this study makes an original contribution. Firstly, the findings of the article show that TM practices on engineers are at best described as a spectrum of stereotypes to organisational practice. Although organisations strive to anticipate their employees' job and employment expectations, many nevertheless struggle to keep their talented and skilled employees (Mohammed et al., 2020a). Thus, this article facilitates organisations by emphasising the need to manage engineers' retention behaviours and employment demands to improve retention rates. Further, an organisation's TM practices for a skilled workforce are an essential part of employee retention and HR strategic planning (Guðmundsdóttir \& Helgudóttir, 2018). The findings of the article contribute to the manufacturing organisation's HR decision-maker to review and revise the TM practices for the engineers.

Secondly, research focusing on exclusive approach to TM practices on specific talent has been generally passive, partly because of the organisational HRM belief that HR practices can be universally applied to all kind of organisations and employees with equal success. There were less focused in the literature on TM practices on engineers (Anlesinya, Dartey-Baah, et al., 2019). This article casts aspersions to this view and seeks to assert that, on the contrary, TM practices that work on engineers in manufacturing sectors are different from and may not work on other talent and sectors. Thus, this article fills the gaps in the literature and loosely coupled integration of TM-ITS of engineers from the behavioural-related theories (e.g., the proposed conceptual model is the combination of underpinning theories, SET and RBV theory).

Finally, based on previous recommendations and theoretical gaps, this article also contributes to developing a model of ITS that integrates the TM dimensions to suggest behavioural factors 
that retain engineers within manufacturing companies. Further, previous researchers have highlighted the TM roles contribute to individual employees' ITS at all levels of positions from the banking sector, multinational organisations, the mining sector, the higher learning institutions, etc. (Gupta, 2019a; Plessis et al., 2015). However, very little scholarly research has addressed the specific issues involved in managing individual engineers in manufacturing sector (Nittala \& Jesiek, 2018; Ramli, 2016). Thus, the findings help us to reconcile the previous conflicting arguments about the applicability of those theories to explain TM practices on engineers' retention in manufacturing sector.

\section{Conclusion}

From the foregoing, this article has shown the possibilities and factors affecting the implementation of TM in the manufacturing sector. It was therefore suggested that manufacturing sector engineers be defined as those individuals who possess specific and unique KSAs that reflect the manufacturing sector and the nation's growth. Additionally, TM within manufacturing sector is characterised by the implementation of a set of significant TM practices which ensure fit within this context to address complex challenges, especially in terms of engineers' shortage and low retention rate. Thus, it is vital to focus on TM practices (e.g., performance management, career development, and employer branding) in the sense of supporting an engineer's career development opportunities and ITS.

\section{Acknowledgments}

This study was supported by publication funds under Universiti Teknologi MARA, Melaka, Malaysia.

\section{References}

Abdul Hamid, S. N. (2016). Linking Person-Job Fit To Employees' Retention: The Mediating Role of Work Engagement. August 2016, 702-709. https://doi.org/10.15405/epsbs.2016.08.99

Abdull Rahman, R. H. (2012). The Impact of Human Resource Strategies on the Retention of Engineers in Malaysian Firms. September, 1-331.

Ahmed, E. M., \& Yang, T. K. (2017). High Attrition Rate Determinants: Case Study of the Malaysian ICT Sector. Journal of Information and Knowledge Management, 16(3), 1-25. https://doi.org/10.1142/S0219649217500307

Alias, N. E., Othman, R., Loon, K. W., Ridzuan, A. R., \& Krishnan, R. (2017). Towards effective employee retention strategy: Implementation of talent management in information, communication and technology companies. Advanced Science Letters, 23(8), 7857-7860. https://doi.org/10.1166/asl.2017.9594

Alias, N. E., Roni, S. M., Merga, M. K., \& Ismail, I. (2017). Rethinking of talent management practices as an employee retention strategy in emerging economy. The Proceedings of 2nd Business Doctoral and Emerging Scholars Conference, 144.

Alias, N. E., Roni, S. M., Merga, M. K., Ismail, I., Ezaili Alias, N., Mat Roni, S., Merga, M. K., \& Ismail, I. (2017). Rethinking of talent management practices as an employee retention strategy in emerging economy. The Proceedings of 2nd Business Doctoral and Emerging Scholars Conference, 144.

Alves, D., Dieguez, T., \& Conceição, O. (2020). Retaining talents: Impact on innovation. Proceedings of the 15th European Conference on Management, Leadership and Governance, ECMLG 2019, 36-45. https://doi.org/10.34190/MLG.19.078 
Alves, P., Santos, V., Reis, I., Martinho, F., Martinho, D., Sampaio, M. C., Sousa, M. J., \& AuYong-oliveira, M. (2020). Strategic talent management: The impact of employer branding on the affective commitment of employees. Sustainability (Switzerland), 12(23), 1-21. https://doi.org/10.3390/su12239993

Ambler, T., \& Barrow, S. (1996). The employer brand. Journal of Brand Management, 4(3), 185-206. https://doi.org/10.1057/bm.1996.42

Anlesinya, A., Amponsah-Tawiah, K., \& Dartey-Baah, K. (2019). Talent management research in Africa: towards multilevel model and research agenda. African Journal of Economic and Management Studies, 10(4), 440-457. https://doi.org/10.1108/AJEMS-12-20180371

Anlesinya, A., Dartey-Baah, K., \& Amponsah-Tawiah, K. (2019). Strategic talent management scholarship: a review of current foci and future directions. Industrial and Commercial Training, 51(5), 299-314. https://doi.org/10.1108/ICT-11-2018-0095

Anvari, R., Mansor, N. N. A., Rahman, S. A. P. A., Rahman, R. H. A., \& Idrus, M. I. S. (2014). The Impact of Learning and Development Initiatives on the Retention of Engineers in Malaysian Firms. Procedia - Social and Behavioral Sciences, 129, 172-177. https://doi.org/10.1016/j.sbspro.2014.03.663

ASEAN Federation of Engineering Organisations. (2021). What is AFEO? AFEO.

Backhaus, K., \& Tikoo, S. (2004). Conceptualizing and researching employer branding. Career Development International, 9(5), 501-517. https://doi.org/10.1108/13620430410550754

Baharin, N. L., \& Hanafi, W. N. W. (2018). Effects of Talent Management on Employee Retention: A Case Study of Hospitality Industry. Global Business and Management Research: An International Journal, 10(3), 697-708.

Bangwal, D., \& Tiwari, P. (2019). Workplace environment, employee satisfaction and intent to stay. International Journal of Contemporary Hospitality Management, 31(1), 268-284. https://doi.org/10.1108/IJCHM-04-2017-0230

Barney, J. (1991). Firm Resources and Sustained Competitive Advantage. Journal of Management, 17(1), 99-120. https://doi.org/10.1177/014920639101700108

Barney, J. (2001). Resource-based theories of competitive advantage: A ten-year retrospective on the resource-based view. Journal of Management, 27(6), 643-650. https://doi.org/10.1016/S0149-2063(01)00115-5

Bass, J. M., Beecham, S., Razzak, M. A., \& Noll, J. (2018). Employee retention and turnover in global software development: Comparing in-house offshoring and offshore outsourcing. Proceedings - International Conference on Software Engineering, 82-91. https://doi.org/10.1145/3196369.3196375

Bethke-Langenegger, P., Mahler, P., \& Staffelbach, B. (2011). Effectiveness of talent management strategies Pamela. European J. International Management, 5(5), 524-539.

Bigliardi, B., Petroni, A., Ivo Dormio, A., Barbara, B., Alberto, P., \& Dormio, A. I. (2005). Organizational socialization, career aspirations and turnover intentions among design engineers. Leadership \& Organization Development Journal, 26(6), 424-441. https://doi.org/10.1108/01437730510617645

Blau, P. (1964). Social Exhange Theory. Retrived Septermber 3 2007, 1(1), 62.

Blau, P. M. (2017). Exchange and power in social life. In Exchange and Power in Social Life. https://doi.org/10.4324/9780203792643

Chamchan, C., \& Kittisuksathit, S. (2019). Generation Y employees in Thai workplaces: What make them stay or leave. Asia-Pacific Social Science Review, 19(1), 49-65. 
Collings, D. G., \& Mellahi, K. (2009). Strategic talent management: A review and research agenda. Human Resource Management Review, 19(4), 304-313.

https://doi.org/10.1016/j.hrmr.2009.04.001

Cooke, F. L., Saini, D. S., \& Wang, J. (2014). Talent management in China and India: A comparison of management perceptions and human resource practices. Journal of World Business, 49(2), 225-235. https://doi.org/10.1016/j.jwb.2013.11.006

Deloitte. (2020). Manufacturing Industry Outlook 2020. In Deloitte.

Doh, J. P., Smith, R. R., Stumpf, S. A., \& Tymon, W. G. (2011). Pride and professionals: Retaining talent in emerging economies. Journal of Business Strategy, 32(5), 35-42. https://doi.org/10.1108/02756661111165453

DOSM. (2020a). Labour Market Review, Malaysia Second Quarter 2020. In Department of Statistics Malaysia.

https://www.dosm.gov.my/v1/index.php?r=column/cthemeByCat\&cat=100\&bul_id=R 09wdGZSektvNmw5T1VCeVphNXRqdz09\&menu_id=TE5CRUZCblh4ZTZMODZIbmk2aW RRQT09

DOSM. (2020b). Monthly Manufacturing Statistics, Malaysia (September 2020). In Department of Statistics Malaysia (Issue November).

Eltaybani, S., Noguchi-Watanabe, M., Igarashi, A., Saito, Y., \& Yamamoto-Mitani, N. (2018). Factors related to intention to stay in the current workplace among long-term care nurses: A nationwide survey. International Journal of Nursing Studies, 80(August 2017), 118-127. https://doi.org/10.1016/j.ijnurstu.2018.01.008

Eom, M., Gudigantala, N., \& Kim, Y. J. (2019). Investigating the process of developing and retaining competent IT personnel: The role of IT leadership. Asia Pacific Journal of Information Systems, 29(1), 83-116. https://doi.org/10.14329/apjis.2019.29.1.83

Espinoza, A., Rojas, E., Rojas, J., \& Raymundo, C. (2019). Methodology for Reducing Staff Turnover in Service Companies Based on Employer Branding and Talent Management. Proceedings of the 4th Brazilian Technology Symposium (BTSym'18), 140, 575-583. https://doi.org/10.1007/978-3-030-16053-1

Fazil, N. (2020). Malaysia's Top In-Demand Jobs for 2020 / EduAdvisor (p. 1). https://eduadvisor.my/articles/malaysias-top-in-demand-jobs-for-2020/

Festing, M., \& Schäfer, L. (2014). Generational challenges to talent management: A framework for talent retention based on the psychological-contract perspective. Journal of World Business, 49(2), 262-271. https://doi.org/10.1016/j.jwb.2013.11.010

Gandy, R., Harrison, P., \& Gold, J. (2018). Talent management in higher education: is turnover relevant? European Journal of Training and Development, 42(9), 597-610. https://doi.org/10.1108/EJTD-11-2017-0099

Guðmundsdóttir, S., \& Helgudóttir, J. (2018). Selection and retention of talent. International Journal of Work Organisation and Emotion, 9(1), 36-44. https://doi.org/10.1504/IJWOE.2018.10012434

Gupta, V. (2019a). Talent management dimensions and its relationship with Generation Y employee's intention to quit: an Indian hotel perspective. International Journal of Tourism Cities, 6(3), 583-600. https://doi.org/10.1108/IJTC-02-2019-0018

Gupta, V. (2019b). Talent management dimensions and their relationship with retention of Generation- $Y$ employees in the hospitality industry. International Journal of Contemporary Hospitality Management, 31(10), 4150-4169.

https://doi.org/10.1108/IJCHM-10-2018-0859

Harun, W. S. W. (2020). Malaysia hungers for more Professional Engineers. In UMP News. 
http://news.ump.edu.my/experts/malaysia-hungers-more-professional-engineers IEM. (2020). Institution of Engineers, Malaysia (IEM).

lles, P., Chuai, X., \& Preece, D. (2010). Talent Management and HRM in Multinational companies in Beijing: Definitions, differences and drivers. Journal of World Business, 45(2), 179-189. https://doi.org/10.1016/j.jwb.2009.09.014

ILMIA. (2018). Environmental Scan for the Human Capital Issues within the Professional Services Activities Sector.

Ingersoll, L. (2002). Human Resource Management in Australia: Strategy, People, Performance [Book Review]. In International Employment Relations Review (Vol. 8, Issue 2). McGraw Hill.

Isa, A., Ibrahim, H. I., Jaaffar, A. H., \& Baharin, N. L. (2018). Talent Management Practices, Perceived Organizational Support and Employee Retention: Evidence From Malaysian Government-Linked Companies. Global Business and Management Research, 10(3), 688. http://search.proquest.com.ezaccess.library.uitm.edu.my/docview/2159620684?accou ntid $=42518$

Khalid, K., \& Nawab, S. (2018). Employee Participation and Employee Retention in View of Compensation. SAGE Open, 8(4). https://doi.org/10.1177/2158244018810067

Lee, T. W., Hom, P., Eberly, M., \& Li, J. (Jason). (2018). Managing employee retention and turnover with 21st century ideas. Organizational Dynamics, 47(2), 88-98. https://doi.org/10.1016/j.orgdyn.2017.08.004

Lejdeby, N., \& Östman, C. (2019). How to Win the War for Talent among Professional Engineers: An Employer Branding Perspective. Luleå University of Technology.

Lepak, D. P., \& Snell, S. A. (1999). The Human Resource Architecture: Toward a Theory of Human Capital Allocation and Development. The Academy of Management Review, 24(1), 31. https://doi.org/10.2307/259035

Letchmiah, L., \& Thomas, A. (2017). Retention of high-potential employees in a development finance company. SA Journal of Human Resource Management, 1(2), 1-10. https://doi.org/10.4102/sajhrm.v15i0.924

Li, J., Hedayati-Mehdiabadi, A., Choi, J., Wu, F., \& Bell, A. (2018). Talent management process in Asia: a multiple case study. European Journal of Training and Development, 42(7-8), 499-516. https://doi.org/10.1108/EJTD-04-2018-0035

Lloyd, S. (2002). Branding from the inside out. Business Review Weekly - BRW.

Maheshwari, V., Gunesh, P., Lodorfos, G., \& Konstantopoulou, A. (2017). Exploring HR practitioners' perspective on employer branding and its role in organisational attractiveness and talent management. International Journal of Organizational Analysis, 25(5), 742-761. https://doi.org/10.1108/IJOA-03-2017-1136

Maurya, K. K., \& Agarwal, M. (2018). Organisational talent management and perceived employer branding. International Journal of Organizational Analysis, 26(2), 312-330. https://doi.org/10.1108/IJOA-04-2017-1147

McDonnell, A., Collings, D. G., Mellahi, K., \& Schuler, R. (2017). Talent management: A systematic review and future prospects. European Journal of International Management, 11(1), 86-128. https://doi.org/10.1504/EJIM.2017.081253

Mensah, J. K. (2019). Talent management and talented employees' attitudes: mediating role of perceived organisational support. International Review of Administrative Sciences, 85(3), 527-543. https://doi.org/10.1177/0020852319844318

MIDA. (2019). Malaysia Investment Performance Report 2019. In Malaysian Invesment Development Authority. 
https://www.mida.gov.my/home/administrator/system_files/modules/photo/uploads/ 20200421151258_MIDA IPR 2019 fullbook_FINAL.pdf

MIDA Insights. (2020). COVID-19: A Catalyst for Malaysia's Industry 4.0. MIDA.

Mitchell, B., Rosse, J., \& Newhall, T. (2004). Reliability algorithms for network swapping systems with page migration. In Proceedings - IEEE International Conference on Cluster Computing, ICCC. Percetakan Nasional Malaysia Berhad.

https://doi.org/10.1109/CLUSTR.2004.1392655

Mohammed, A. A., Baig, A. H., \& Gururajan, R. (2020). An examination of talent management processes in Australian higher education. International Journal of Productivity and Performance Management, 69(6), 1271-1299. https://doi.org/10.1108/IJPPM-10-20180352

Mwanzi, J., Wamitu, S., \& Kiama, M. (2017). Influence of Talent Management on Organizational Growth. IOSR Journal of Business and Management, 19(8), 1-36. https://doi.org/10.9790/487X-1908080136

Narayanan, A., Rajithakumar, S., \& Menon, M. (2019). Talent Management and Employee Retention: An Integrative Research Framework. Human Resource Development Review, 18(2), 228-247. https://doi.org/10.1177/1534484318812159

Neri, S., \& Wilkins, S. (2019). Talent management in transnational higher education: strategies for managing academic staff at international branch campuses. Journal of Higher Education Policy and Management, 41(1), 52-69.

https://doi.org/10.1080/1360080X.2018.1522713

Ngan, H. F. B., \& Vong, T-N. L. (2019). Hospitality employees' unrealistic optimism in promotion perception: myth or reality? Journal of Human Resources in Hospitality and Tourism, 18(2), 172-193. https://doi.org/10.1080/15332845.2019.1558480

Nittala, S., \& Jesiek, B. K. (2018). Managing engineering talent in organizations: A qualitative systematic literature review on engineering talent management. ASEE Annual Conference and Exposition, Conference Proceedings, 2018-June. https://doi.org/10.18260/1-2--30785

Osman, I., Noordin, F., Mohd, I. H., \& Wei-Loon, K. (2017). The Role of Entrepreneurial Orientations in Talent Retention Amongst Malaysian Engineers. International Journal of Management Studies, 25(1), 105-132. https://doi.org/10.32890/ijms.25.1.2018.10495

Osman, I., Noordin, F., Mohd, I. H., \& Wei-Loon, K. (2018). The Role of Entrepreneurial Orientations in Talent Retention Amongst Malaysian Engineers. International Journal of Management Studies, 24(2), 1-24.

Palmer, A. (2003). The war for talent. In RUSI Journal (Vol. 148, Issue 2). Harvard Business Press. https://doi.org/10.1080/03071840308446873

Pant, J. J., \& Venkateswaran, V. (2019). Exploring millennial psychological contract expectations across talent segments. Employee Relations, 41(4), 773-792. https://doi.org/10.1108/ER-04-2018-0096

Paré, G., \& Tremblay, M. (2007). The influence of high-involvement human resources practices, procedural justice, organizational commitment, and citizenship behaviors on information technology professionals' turnover intentions. Group and Organization Management, 32(3), 326-357. https://doi.org/10.1177/1059601106286875

Plessis, L. Du, Barkhuizen, N., Stanz, K., \& Schutte, N. (2015). The management side of talent: Causal implications for the retention of generation y employees. Journal of Applied Business Research, 31(5), 1767-1780. https://doi.org/10.19030/jabr.v31i5.9390

Poisat, P., Mey, M. R., \& Sharp, G. (2018). Do talent management strategies influence the 
psychological contract within a diverse environment? SA Journal of Human Resource Management, 16, 1-10. https://doi.org/10.4102/sajhrm.v16i0.1044

Rahim, N. A., Mohamed, Z. B., Amrin, A., \& Mohammad, R. (2019). Women's Dual Roles and Career Growth: A Preliminary Study of Malaysian Female Talents in Science, Engineering and Technology (SET). Journal of Physics: Conference Series, 1174(1). https://doi.org/10.1088/1742-6596/1174/1/012013

Rahman, R. H. A. (2012). "Malaysian firms" role in retaining engineers. Economic and Labour Relations Review, 23(4), 57-77. https://doi.org/10.1177/103530461202300405

Ramaiah, R. A. T. S. (2014). a Study on Talent Management Practices in Corporate World. International Journal of Organizational Behaviour \&amp; Management Perspectives, 3(1), 766-769.

Ramli, N. S. (2016). Product Development Strategy - Innovation Capacity and Entrepreneurial Firm Performance in High-tech SMEsProduct Development Strategy - Innovation Capacity and Entrepreneurial Firm Performance in High-tech SMEs. International Journal of Entrepreneurial Behavior \& Research, 22(6), 985-988. https://doi.org/10.1108/ijebr02-2016-0064

Rezaei, F., \& Beyerlein, M. (2018). Talent development: a systematic literature review of empirical studies. European Journal of Training and Development, 42(1/2), 75-90. https://doi.org/10.1108/EJTD-09-2017-0076

Shikweni, S., Schurink, W., \& Van Wyk, R. (2019). Talent management in the south african construction industry. SA Journal of Human Resource Management, 17, 1-12. https://doi.org/10.4102/sajhrm.v17i0.1094

Nivedhan, S., \& Priyadarshini, R. G. (2018). Gamification Elements used in Employee Retention and Enhancing Employee Productivity. IOP Conference Series: Materials Science and Engineering, 390(1). https://doi.org/10.1088/1757-899X/390/1/012039

Singh, A., \& Sharma, J. (2015). Strategies for talent management: A study of select organizations in the UAE. International Journal of Organizational Analysis, 23(3), 337347. https://doi.org/10.1108/IJOA-11-2014-0823

Singh, R., Fouad, N. A., Fitzpatrick, M. E., Liu, J. P., Cappaert, K. J., \& Figuereido, C. (2013). Stemming the tide: Predicting women engineers' intentions to leave. Journal of Vocational Behavior, 83(3), 281-294. https://doi.org/10.1016/j.jvb.2013.05.007

Sinniah, S., Mohamed, R. K. M. H., Mior, W. R., Harith, A., Izni, W. N., \& Rawshdeh, Z. A. (2019). Talent retention in private universities of Malaysia. International Journal of Engineering and Advanced Technology, 8(6 Special Issue 3), 233-239. https://doi.org/10.35940/ijeat.F1038.0986S319

Smyth, I., \& Zimba, C. (2019). An investigation into apprenticeship completion and retention in Northern Ireland: a social exchange perspective. International Journal of Training and Development, 23(1), 89-115. https://doi.org/10.1111/ijtd.12146

Sparrow, P. (2019). Management Debate. Cuadernos de Economía y Dirección de La Empresa, 22(3), 160-170. https://doi.org/10.1016/j.brq.2019.05.001

Stahl, G., Björkman, I., Farndale, E., Morris, S. S., Paauwe, J., Stiles, P., Trevor, J., \& Wright, P. (2012). Global Talent Management: How Leading Multinationals Build and Sustain Their Sustain Their Talent Pipeline. WU Vienna University of Economics and Business, 1(September), 25-42. http://epub.wu.ac.at/2792/

StudyMalaysia.com. (2020). Careers in the time of Covid-19 - StudyMalaysia.

Subramaniam, C., Choo, L. S., \& Johari, J. (2019). What makes employees want to stay? A study in the Malaysian manufacturing sector. Global Business and Organizational 
Excellence, 38(5), 33-43. https://doi.org/10.1002/joe.21949

Sutherland, M., \& Jordaan, W. (2004). Factors to retention of knowledge workers. Journal of Human Resource Management, 2(2), 55-64.

Tanwar, K., \& Prasad, A. (2016). Exploring the Relationship between Employer Branding and Employee Retention. Global Business Review, 17, 186S-206S. https://doi.org/10.1177/0972150916631214

Tlaiss, H. A., Martin, P., \& Hofaidhllaoui, M. (2017). Talent retention: evidence from a multinational firm in France. Employee Relations, 39(4), 426-445. https://doi.org/10.1108/ER-07-2016-0130

Tymon, W. G., Stumpf, S. A., \& Doh, J. P. (2010a). Exploring talent management in India: The neglected role of intrinsic rewards. Journal of World Business, 45(2), 109-121. https://doi.org/10.1016/j.jwb.2009.09.016

Tymon, W. G., Stumpf, S. A., \& Doh, J. P. (2010b). Exploring talent management in India: The neglected role of intrinsic rewards. Journal of World Business, 45(2), 109-121. https://doi.org/10.1016/j.jwb.2009.09.016

Valeau, P., Paille, P., Dubrulle, C., \& Guenin, H. (2019). The mediating effects of professional and organizational commitment on the relationship between HRM practices and professional employees' intention to stay. International Journal of Human Resource Management, O(0), 1-37. https://doi.org/10.1080/09585192.2018.1559870

Van Hoek, L., \& Schultz, C. (2013). Performance management and remuneration as main dimensions of talent management in a natural resources mining company in Africa. 2013 Proceedings of PICMET 2013: Technology Management in the IT-Driven Services, September, 1935-1943.

Vnouckova, L., Urbancova, H., \& Smolova, H. (2018). Building employer image thanks to talent programmes in Czech organisations. Engineering Economics, 29(3), 319-331. https://doi.org/10.5755/j01.ee.29.3.13975

WFEO. (2020a). Engineering: Stepping up to the challenge of coronavirus and other global threats (Issue March).

WFEO. (2020b). World Federation of Engineering Organisations (WFEO) Report (pp. 1-16). World Federation of Engineering Organizations (WFEO).

Whysall, Z., Owtram, M., \& Brittain, S. (2019). The new talent management challenges of Industry 4.0. Journal of Management Development, 38(2), 118-129. https://doi.org/10.1108/JMD-06-2018-0181

Yee, C. C., Husna, R., Rahman, A., \& Syakira, A. (2012). The Relationship between Training, Learning and Career Development Strategies on Engineers' Intention to Stay. 1-9. http://www.akademiabaru.com/wvsocial/temp/hum1.pdf

Yelamanchili, R. K. (2018). Relationship between leader behavior and subordinate intention to remain: mediating role of critical thinking and empowerment. Academy of Strategic Management Journal, 17(1), 1-16.

Younas, M., \& Bari, M. W. (2020). The relationship between talent management practices and retention of generation ' $\mathrm{Y}$ ' employees: mediating role of competency development. Economic Research-Ekonomska Istrazivanja , 33(1), 1330-1353. https://doi.org/10.1080/1331677X.2020.1748510

Zeeshan, M. (2020a). Transformational Leadership and Corporate Reputation: Mediation Effects of Employer Branding. Journal of Management and Research, 7(1), 184-211.

Zeeshan, M. (2020b). Transformational Leadership and Corporate Reputation: Mediation Effects of Employer Branding. Journal of Management and Research, 7(1), 184-211. 
INTERNATIONAL JOURNAL OF ACADEMIC RESEARCH IN BUSINESS AND SOCIAL SCIENCES Vol. 12, No. 1, 2022, E-ISSN: 2222-6990 @ 2022 HRMARS

Zheng, C. (2009). Keeping talents for advancing service firms in Asia. Journal of Service Management, 20(5), 482-502. https://doi.org/10.1108/09564230910995107 